\title{
Correction to: Stearic sunflower oil as a sustainable and healthy alternative to palm oil. A review
}

\author{
Anushree Sanyal $^{1,2} \cdot$ André Merrien $^{3} \cdot$ Guillaume Decocq $^{1} \cdot$ Frédéric Fine $^{3}$
}

Published online: 22 August 2018

(C) INRA and Springer-Verlag France SAS, part of Springer Nature 2018

Correction to: Agron. Sustain. Dev. (2017): 18 https://doi.org/10.1007/s13593-017-0426-x

Due to an unfortunate turn of events, the names of the authors appeared incorrectly in the original publication as given names and family names have been reversed. The correct representation of the authors' names is listed above and below and should be treated as definitive.

In the 'Cite this article as' section at Springer Link the reference to the article should read:

Sanyal, A., Merrien, A., Decocq, G. et al. Agron. Sustain. Dev. (2017) 37: 18. https://doi.org/10.1007/s13593-017-0426-x

Please use this information in future citations.

We apologize to authors and readers for the inconvenience.

The online version of the original article can be found at https://doi.org/ 10.1007/s13593-017-0426-x

Anushree Sanyal

anushree.sanyal@ebc.uu.se

André Merrien

a.merrien@terresinovia.fr

Guillaume Decocq

guillaume.decocq@u-picardie.fr

Frédéric Fine

f.fine@terresinovia.fr

1 Unité "Ecologie et Dynamique des Systèmes Anthropisés"

(EDYSAN, FRE 3498 CNRS), Université de Picardie Jules Verne, 1 rue des Louvels, FR-80037 Amiens Cedex, France

2 Department of Organismal Biology, Systematic Biology, Uppsala University, 75236 Uppsala, Sweden

3 Terres Inovia, 11 rue de Monceau, Cedex 08, 75378 Paris, France 